Windle, J. (2016). 'Preventing the Diversion of Turkish Opium'. Security Journal, 29(2), pp. 213-227. Pre-publication copy

\title{
Preventing the diversion of Turkish opium
}

\author{
James Windle ${ }^{1}$ \\ The final version of the paper as published in the print edition can be found at: \\ http://www.palgrave-journals.com/sj/journal/v29/n2/abs/sj20138a.html \\ ${ }^{1}$ Royal Docklands School of Business and Law, University of East London, \\ J.Windle@uel.ac.uk
}

\begin{abstract}
Turkey was once one of the world's largest sources of illicit opium; the majority diverted from sparsely regulated licit production. Since 1972, however, it has contributed almost no opium to the global black market. As such, Turkey is one of a small number of states to have eradicated, or severally reduced, the national supply of illicit opium. This article reconsiders post-1974 Turkish controls from a situational crime prevention perspective. It is suggested that Turkish success was founded upon reducing opportunities for diversion from regulated production by hardening targets, increasing formal and informal surveillance, assisting compliance through fair procurement practices and increasing the risk of non-compliance.
\end{abstract}

Key words: situational crime prevention; agricultural theft; opium; Turkey; diversion 
Windle, J. (2016). 'Preventing the Diversion of Turkish Opium'. Security Journal, 29(2), pp. 213-227. Pre-publication copy

\section{Introduction}

Turkey was once one of the world's largest sources of illicit opium. Since 1972, however, it has contributed almost no opium to the global black market. As such, Turkey is one of a small number of states to have eradicated, or severally reduced, the national supply of illicit opium. Although the intervention has been well documented by a range of academic disciplines (see Spain, 1975; Brundage and Mitchell, 1977; West, 1992; Mansfield, 2001; Robins, 2007; Evered, 2011a), it has yet to be analysed from the perspective of crime prevention. The lack of attention this agricultural theft prevention and drug control intervention has received from criminology might be surprising if it were not for the general lack of attention devoted to rural crimes (Donnermeyer and Barclay, 2005; Mears et al, 2007).

This article reconsiders the post-1974 Turkish controls from the perspective of situational crime prevention (SCP). It is suggested that success was founded upon reducing opportunities for diversion ${ }^{1}$ to black markets by hardening targets, increasing formal and informal surveillance, assisting compliance through fair procurement practices and increasing the risk of non-compliance. Implementation was supported by state and implementing institutions (including farming communities) being motivated by economic, institutional and political self-interest. In addition, the policy started from an informed foundation, and continued with focused aims and objectives.

Before commencing, it is worth noting that while this article is concerned with the prevention of a specific offence (opium diversion), the Turkish intervention discussed hereafter was not part of a wider policy to disrupt illicit opiate distribution. Rather, Turkey's centrality as a major transit area for illicit opiates has been facilitated by 'weak, corrupt and inconsistent' counter-trafficking policies (Paoli et al, 2009, p. 287; McLeod, 1980; Robins, 2008). Although there have been improvements since the mid-1990s (Robins, 2008), Turkish state employees have protected (and profited from) traffickers and opiate manufacturers connected to paramilitary groups and Kurdish clans allied with the state (Bovenkerk and Yesilgöz, 2006; Paoli et al,

\footnotetext{
1 'Diversion' is the rather innocuous-sounding technical term by which drug policy refers to the theft of opium at any point along regulated production and distribution lines. This is different to illicit production, which is the clandestine extraction of the juice of the opium poppy
} 
Windle, J. (2016). 'Preventing the Diversion of Turkish Opium'. Security Journal, 29(2), pp. 213-227. Pre-publication copy

2009; Robins, 2008). Although this does not necessarily deflect from Turkish achievements in preventing diversion, it does suggest that a holistic counter-narcotics policy was not undertaken. Rather, resources were strategically applied to a segment of the distribution chain, which supported Turkey's economic and political interests. Before discussing Turkish opium production, a brief overview of SCP will be provided.

The primary theoretical assumptions of SCP are that offenders are rational actors (Cornish and Clarke, 2008) and offences can be reduced by blocking, reducing or removing the opportunities that make crime (diversion in this case) more likely (Clarke, 2008). An 'overriding principle' is to create preventive measures that change the 'near' situational causes of crime, rather than 'distant' causes of crime, such as poverty, inequality or upbringing. Although tackling distant causes may reduce offending in the future, changing the opportunity structure can often create immediate and direct reductions (Clarke, 2008, p. 180). Turkish farmers, for example, may have diverted opium due to poverty or alienation from urban centres of politics. While it may have taken decades to reduce poverty and alienation, changes to the opportunity structure produced immediate tangible benefits. Furthermore, reducing poverty and political alienation should have been policy objectives regardless of their assumed impact on diversion.

The prevention of situational causes of crime is achieved by using any combination of 25 techniques, categorised under five headings (Clarke, 2008):

1) Reduce the rewards (harden target, control access to facilities, screen exits, deflect offenders, controls tools/weapons).

2) Increase the difficulty (extend guardianship, assist natural surveillance, reduce anonymity, use place managers, strengthen formal surveillance).

3) Increase the effort (conceal targets, remove targets, identify property, disrupt markets, deny benefits).

4) Reduce provocations (reduce frustrations and stress, avoid disputes, reduce temptation and arousal, neutralise peer pressure, discourage imitation).

5) Remove excuses (set rules, post instructions, alert conscience, assist compliance, control drugs and alcohol). 
Windle, J. (2016). 'Preventing the Diversion of Turkish Opium'. Security Journal, 29(2), pp. 213-227. Pre-publication copy

This article argues that from 1974 Turkey used a combination of these 25 techniques to successfully prevent the diversion of opium from the state monopoly. To set the scene, the historical context to Turkish opium production and diversion between the 1920s and 1974 will be provided (for a more in-depth analysis of this period see Windle, forthcoming). During this contextual discussion, the limitations of pre-1974 controls will be explored. The concluding sections will analyse post-1974 Turkish controls by using a SCP framework and then discussing how, and why, the intervention was implemented.

\section{Late-1920s to 1960s: Increasing Supply and Controls}

Although Turkey had been a major global source of opium from the early nineteenth century (Spain, 1975), increasing demand from the European opiate manufacturers during the late 1920s/early 1930s inflated Turkish opium production (Eisenlohr, 1934) from already significant levels. By the early 1930s, Turkey was the world's primary source of opium to the licit and illicit pharmaceutical industry; contributing $226 \mathrm{mt}$ of the $390 \mathrm{mt}$ total global supply of opium (Eisenlohr, 1934; see Block, 1989; Schmidt, 1998).

Turkish opium supplied French and Italian pharmaceutical companies, which illicitly exported heroin and morphine for recreational consumption. In 1928, for example, France imported three times the total global medicinal requirement of opium from Turkey (Block, 1989; see Meyer and Parssinen, 2002). Domestic opiate laboratories also used Turkish opium: few manufactured opiates for medicinal/scientific purpose (Times, 1931; League of Nations, 1936). In 1931, Turkey was suspected of producing at least $14 \mathrm{mt}$ of unsupervised heroin and morphine every month in three factories in Istanbul (Schmidt, 1998). As the average ratio of opium to heroin is 10:1 (Zerel et al, 2005), the three opiate factories would have used approximately $140 \mathrm{mt}$ of opium per month (Windle, forthcoming).

After ratifying the International Opium Convention in 1933, Turkey enacted its first domestic drug control legislation (Government of Turkey, 1986a; West, 1992): the Limitations Law (No. 2253) (Bulletin of Narcotics, 1950). Under the law, farmers could only cultivate opium in provinces with the government's permission (Bulletin of Narcotics, 1950). The state began to gradually restrict permissible production areas to where authority was strongest (Akçasu, 1952; INCB, 1968, 1969, 
Windle, J. (2016). 'Preventing the Diversion of Turkish Opium'. Security Journal, 29(2), pp. 213-227. Pre-publication copy

1971; Greenfield and Nanby, 1974) and away from areas with easy export access (Windle, forthcoming). These bans, however, tended to be administered in provinces with the least significant output (Erinç and Tucdilek, 1952; Government of Turkey, 1986a).

Nominal controls over opium farmers were established in 1938 with the creation of the Toprak Mahsulleri Ofisi (TMO, Soil Products Office): a monopoly mandated to procure, store and export opium, and other agricultural produce (see CND, 1945; TMO-Alkasan, 1989). Control was based on the ineffective 'opium declaration system' (Akçasu, 1952; Lamour and Lamberti, 1974) in which farmers in designated provinces informed their Muhtar (village leader) what they expected to yield in the following season. The expectations were relayed to the Ministry of Agriculture. As farmers were expected to adhere to self-estimations, the system was (naively) based on the honesty of farmers (also League of Nations, 1938; Akçasu, 1952; Murphy and Steele, 1971). All residents of designated provinces were permitted to produce opium without licence and were legally free to possess and store opium (see CND, 1944-1946, 1951-1955, 1957; Bulletin of Narcotics, 1949; Akçasu, 1952). Monitoring was conducted by the Muhtar, who was obliged to inform the TMO of any contravention (CINC, 1972).

The remuneration system was equally ineffective. TMO prices 'neither repaid [farmers] for their troubles and outlay nor gave them the profit they were entitled to expect' (League of Nations, 1938, p. 45). As procurement practices were inefficient (Murphy and Steele, 1971), the majority of farmers continued to illicitly sell a significant percentage of the opium they produced (Akçasu, 1952; Lamour and Lamberti, 1974).

In addition, poppy cultivation was permitted for the harvesting of seeds in many border provinces where opium production was prohibited (Bulletin of Narcotics, 1950). In 1968, Turkey admitted that it had been unable to administer effective controls over farmers in border areas (INCB, 1969, 1971; Greenfield and Nanby, 1974). This suggests that the state was unable to prevent farmers from extracting opium from poppies grown for their seeds (Windle, forthcoming).

Furthermore, state institutions, including tax collection and law enforcement, were generally absent from rural areas before the 1940s, when they 'became more effective and visible' (Rustow, 1967; Zürcher, 1998, p. 216). Agricultural 
Windle, J. (2016). 'Preventing the Diversion of Turkish Opium'. Security Journal, 29(2), pp. 213-227. Pre-publication copy

development policies also increased access to rural areas through improvements in the transport infrastructure (Zürcher, 1998).

Throughout the 1930s, 1940s and 1950s, Turkey remained one of the world's largest sources of illicit opium (League of Nations, 1931; Bulletin of Narcotics, 1953). In 1936, Turkey reported to the League of Nations (1938) that although significant tracts of land were cultivated with opium poppies, the monopoly price had been deflated by decreased foreign demand for medicinal opium. Consequentially, as farmers could not afford to hire labourers, 75-80 per cent of the crop remained unharvested. As controls over production and trade remained nominal, it is unlikely that 75-80 per cent was wasted, but rather diverted to black markets (Windle, forthcoming). This is not unreasonable: in 1941, less than 15 per cent of wheat production was surrendered to the TMO, even though all farmers were obliged (due to war time policy) to sell to the state monopoly. An unknown quantity was sold on the black market (Pamuk, 1991).

\section{The 1960s: Strengthening of Controls}

In the 1960s, to prevent diversion, the TMO increased its prices by 66 per cent, made it easier for farmers to deliver opium to monopoly agents, ensured all farmers were paid with cash (many had previously been paid with food coupons) and publicised penalties for noncompliance (CINC, 1972). Formal surveillance of opium farmers was also increased (Murphy and Steele, 1971).

Regardless of administrative improvements, the monopoly remained a 'sometimes problematic, distant and lower-paying buyer'; often paying as little as 20 per cent less than black market prices. Furthermore, farmers were forced to travel to sell to the state monopoly, whereas black market merchants would often visit villages (Evered, 2011b, p. 179).

These administrative measures and the contraction of provinces did improve the amount surrendered to the monopoly (Turnbull, 1972) and led the UN Permanent Central Opium Board (PCOB) (1965, p. xxix) to note with 'approval' and 'satisfaction' that restrictions were a 'step in the right direction' (PCOB, 1966, p. xx). The 'declaration system', however, remained insufficient: 
Windle, J. (2016). 'Preventing the Diversion of Turkish Opium'. Security Journal, 29(2), pp. 213-227. Pre-publication copy

Since yields varied from year to year, the farmer tended to understate expected yields for he was liable for prosecution if he did not deliver to the ... [TMO] ... the total amount of gum he had reported in his declaration. In general, little effort was made to question farmer declarations or to verify actual yield at harvest time. Thus, this system allowed for considerable opportunity for underreporting yields. (CINC, 1972, p. A3).

One former opium farmer recalled how: 'No permission slips or licenses were required; we just planted as much as we wanted and could harvest'. The primary limitation on opium production, at the time, was the labour intensity of opium gum harvesting, rather than the state (Evered, 2011b, p. 170).

Government control was further diluted by farmer's legal entitlement to possess unlimited quantities of opium (Murphy and Steele, 1971). In addition to bureaucratic weaknesses, the coercive arms of the state tended to be inefficient, under resourced and lacked training in narcotics control (Murphy and Steele, 1971; Newsday, 1974).

Although the level of diversion may have been reduced by the innovations of the 1960s, diversion remained high. In 1961, America complained to the Central Treaty Organisation (CENTO) that 70 per cent of all heroin consumed in America was sourced from French heroin laboratories, supplied by 'Middle Eastern', primarily Turkish, opium. The accusation was not refuted by the Turkish delegate (British Foreign Office, 1961). This was followed, in 1966, by a complaint from Iran that Turkey supplied 25 per cent of its illicit opium supply (British Foreign Office, 1966). By the mid-1960s, the American estimate had increased to 80 per cent (Economist, 1974; Lamour and Lamberti, 1974; Musto, 1987). While this estimate has been heavily criticised (Epstein, 1977; Government of Turkey, 1986a; Uslu, 2003; Evered, 2011a), Turkey was the predominant source of opium for heroin destined for America (Rottenberg, 1968; Murphy and Steele, 1971; McCoy, 2003).

During the mid/late-1960s, there was a divergence of opinion among American sources of the level of diversion. The Drug Enforcement Agency (1995) estimated that one-third of Turkish opium was diverted. The Bureau of Narcotics and Dangerous Drugs compared expected and actual yields (Holahan and Henningsen, 
Windle, J. (2016). 'Preventing the Diversion of Turkish Opium'. Security Journal, 29(2), pp. 213-227. Pre-publication copy

1972; Epstein, 1977) to estimate two-third diversion (cited in Holahan and Henningsen, 1972). The CINC (Committee on International Narcotics Control, 1972, see (Table 2) estimated that diversion decreased from 69.5 to 26 per cent, while an American ambassador to Turkey reported 25 per cent to a journalist (Epstein, 1977). Although the two-third estimate is often critiqued for methodological limitations (Robins, 2007), it was validated by an investigation conducted by reporters from Newsday (1974). Other journalists, conversely, reported 5 (Munir, 1970, cited in Robins, 2007) and 10 per cent by the late 1960s/early 1970s (Howe, 1980) (Table 1).

The Turkish government admitted to the International Narcotics Control Board (INCB) (1974, p. 13) that 'substantial quantities' of opium were diverted during the 1960s. The INCB (1971, p. 13) summarised the 1960s:

Frequent appearance in the illicit traffic of opium, or opium derivatives, known or presumed to have originated from Turkey has made this country a focus of international concern for a number of years. Counter-measures have not been lacking, yet the stream of such substances has persisted and has caused much disquiet ...

To summarise the level of diversion between the 1930s and 1971, reports to the League of Nations (1938) indicate diversion rates of between 75 and 80 per cent in 1936. This estimate can be placed with the estimates provided by the American agencies in the mid/late 1960s (discussed above) to produce three diversion rate parameters, expressed in Figure 1: a high ( 80 per cent), middle (66 per cent) and low (25 per cent) (Windle, 2011).

Fluctuations within these three parameters appear to follow the subsequent trend, as expressed in Figure 1: Diversion appears high (80 per cent) from at least 1936 (possibly peaking after the 1955 Iranian prohibition) to the 1960s when the imposition of more stringent controls make two-thirds (66 per cent) appear likely. By the early 1970s, the low parameter (25 per cent) appears feasible, although diversion may have been as low as 5 per cent (Windle, 2011).

In summary, from the 1940s, Turkish controls were strengthened as the state extended authority into the countryside, while surveillance and procurement practices improved during the 1960s. This said, sanctions remained minimal and deterred few. 
Windle, J. (2016). 'Preventing the Diversion of Turkish Opium'. Security Journal, 29(2), pp. 213-227. Pre-publication copy

Ineffective procurement practices meant that the monopoly was unable to compete with black market traders who offered better prices and procured at the farm gate, while the naive opium declaration system presented significant opportunities for diversion (Windle, forthcoming). In short, Turkey lacked any effective mechanism to provide risks for diversion or rewards for compliance.

This section has provided some background on the size of diversion, and the criminal justice and administrative mechanisms facilitating, or at least not preventing, diversion. The next section will address how Turkey suppressed and prevented largescale diversion of state-regulated opium.

Table 1. CINC diversion estimates

\begin{tabular}{l|lllll}
\hline & 1967 & 1968 & 1969 & 1970 & 1971 \\
\hline Percentage diverted & 69.5 & 52.3 & 46.5 & 58 & 26 \\
In metric tonnes & 205 & 137 & 110 & 80 & 49
\end{tabular}

Source: CINC (1972).

Figure 1. Turkey: Diverted opium (1931-1972)

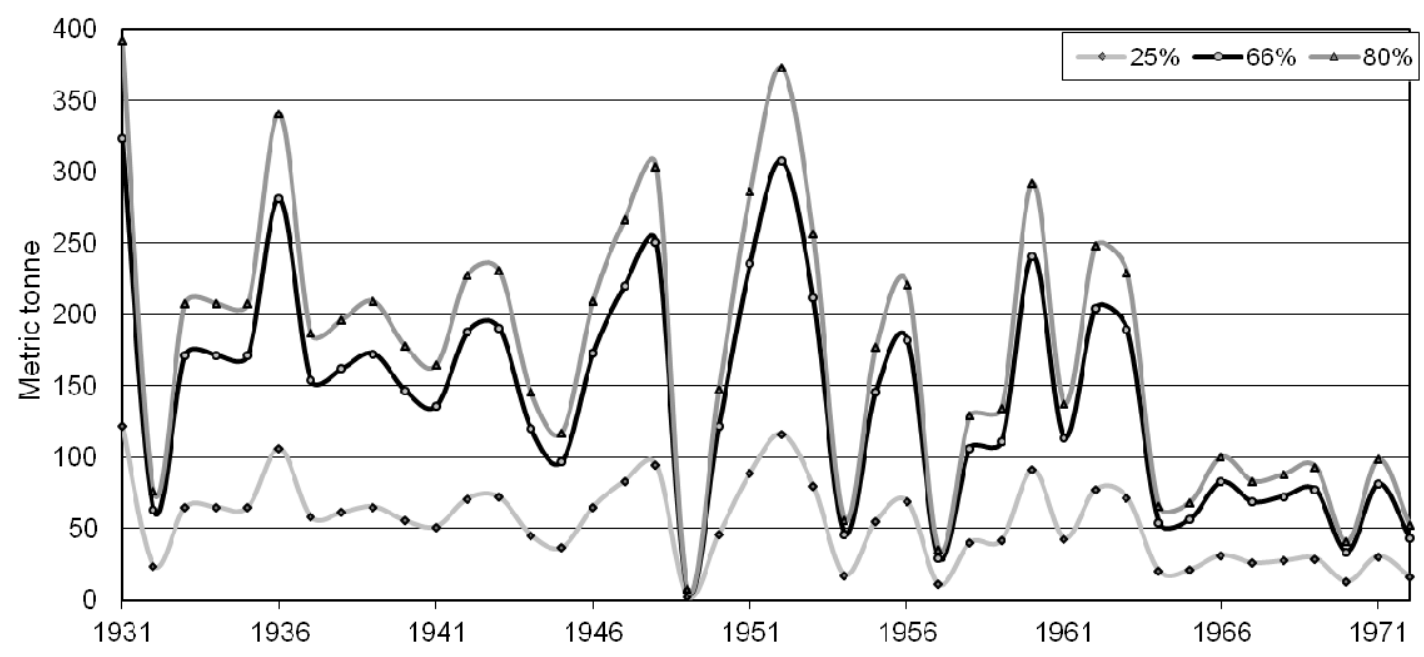

Sources: adapted from, Bulletin of Narcotics (1949, 1950); CINC (1972); Grey (1925); INCB (various years); League of Nations (1941, cited in Block, 1989); PCOB (various years).

\section{Opium Bans: 1971 and 1974}

The 1971 Opium Licensing and Control Law introduced licencing for opium farmers. Individuals with criminal records were barred from obtaining a licence (CINC, 1972), while possession of unlicenced opium was criminalised (GOA, 1972). Then, in the 
Windle, J. (2016). 'Preventing the Diversion of Turkish Opium'. Security Journal, 29(2), pp. 213-227. Pre-publication copy

late 1971, a new military regime banned all opium production, under Decree No. 7/2654 (Kamminga, 2007; Robins, 2007).

Although the ban was successful in terms of drug control (GOA, 1975; INCB, 1972), it was deeply unpopular with rural communities (Klose, 1981; Government of Turkey, 1986a; Evered, 2011a, b), and urban populations who perceived the ban as submissive to American demands (Fyjis-Walker, 1974; Zürcher, 1998; Uslu, 2003; Robins, 2007; Evered, 2011a). In response to extensive opposition, the newly elected civilian government passed Decree No. 7522 in 1974.

This Decree lifted the ban on opium poppy cultivation in seven provinces; however, it remained an offence to produce opium. A monopoly system was established whereby farmers were licenced to cultivate poppy straw (see UNFDAC, 1975; Warren-Gash, 1975; Government of Turkey, 1986a; also Decree No.7/8522, 1974; Decree No.7/9204, 1975). The production of morphine from poppy straw is significantly different from that of incising poppy pods (the previous harvest method). Although the poppy plant is cultivated in the same manner, at harvest the farmer is prohibited from incising the poppy pods to collect the opium gum. Instead, farmers cut and crush the poppies. The crushed poppies (the poppy straw) are then sold to the state. Morphine is then extracted from the straw using specialist and expensive technology (Mansfield, 2001; see Bayer, 1983).

To assist Turkey, the UN part funded the construction of a poppy straw processing plant (Bayer, 1983; Kamminga, 2007). It also lobbied pharmaceutical companies to ensure the procurement of Turkish morphine (British Foreign and Commonwealth Office, 1974) and provided funding for counter-narcotics and rural development (Kamminga, 2007).

\section{Post-1974 Controls}

After 1974, the opium monopoly continued to be administered by the TMO. Before harvest, the Council of Ministers annually instructed how much land, and in which province, could be cultivated with opium, and the number of licences available to each province (Mansfield, 2001). The amount of cultivable land allowed was based on estimates of global opiate needs produced by the INCB (Jensema and Archer, 2005).

Farmers were then permitted to apply to the TMO for a licence (Government of Turkey, 1988) detailing: the size and location of farmland, the type of seed to be 
Windle, J. (2016). 'Preventing the Diversion of Turkish Opium'. Security Journal, 29(2), pp. 213-227. Pre-publication copy

used and irrigation sources. Licences could only be held by farmers who were over 18 years of age, without a criminal record and lived on the land they were licenced to cultivate. Successful applicants were guaranteed by village Muhtars, ${ }^{2}$ who were made accountable for diversion. This placed a considerable social restraint on farmers (see Howe, 1980; Mansfield, 2001; also Jensema and Archer, 2005).

During cultivation, teams of agricultural experts (Ajans) inspected licenced farmers a minimum of six times, formulated an expected yield and administered agricultural advice. To prevent corruption, all inspection results were signed off by an Ajan, the licensee and Muhtar. Excess cultivation was verified by a second team of Ajans (TMO-Alkasan, 1989; Mansfield, 2001). Ground inspections were effective as in 'an otherwise dry environment, scars or blemishes on the capsules are immediately apparent to the eye when walking past such fields' (Evered, 2011c, p. 5). The ground inspections were, nonetheless, supported by aerial surveys of all licenced areas (Greenfield, 1974; Turkish Embassy, London, 1975; Turkish National News, 1981; Government of Turkey, 1988, 1986b). The Muhtar was, furthermore, legally obliged to report any suspicious activities (Alexander, 2002). As the Muhtar was an elected part of the village government (Kolars, 1967), production was monitored by local community representatives. Once opium poppies became ripe for extraction, the TMO and gendarmerie increased their surveillance (UNFDAC, 1986) and placed undercover agents in areas where diversion was suspected (Greenfield and Nanby, 1974; Government of Turkey, 1986b). Taken together, the risk of detection was high (Mansfield, 2001).

The licensee was permitted to harvest the crop (that is, crush the poppies) once the Ajans confirmed that no pods had been lanced. Once harvested, farmers delivered the straw to the Ajans for weighing (UNFDAC, 1986; Government of Turkey, 1988; Mansfield, 2001). The state procured all opium at a generally fair (fixed) price. For example, an opium farmer interviewed by Evered (2011b, p. 180) recalled how she 'hoped that her descendants would be poppy farmers because they would "always have money in hand"'.

\footnotetext{
${ }^{2}$ Muhtars are elected village representatives. They act as brokers between the state and village. Although their salaries are paid by the villagers they represent, they are officially employees of the Ministry of the Interior and legally obliged to report any unusual activity to the Kaymakam (provincial governor) (Alexander, 2002).
} 
Windle, J. (2016). 'Preventing the Diversion of Turkish Opium'. Security Journal, 29(2), pp. 213-227. Pre-publication copy

Deviation from licence agreements could result in civil or criminal punishments. Communal punishments were also imposed. If the surrendered straw was significantly above or below the Ajan's initial yield estimation, the farmer was referred to court (Government of Turkey, 1988; Mansfield, 2001; UNFDAC, 1986). All crops cultivated in excess of the licence agreement were eradicated, the farmer would be banned from obtaining future licences (Decree No. 7/9204, 1975; Government of Turkey, 1986a) and punished with between 1 and 5 years imprisonment (Law No. 3289). ${ }^{3}$ In 1975, 205 farmers who cultivated more than their licence permitted (Government of Turkey, 1986b) had their crops forcefully eradicated, were imprisoned and barred from obtaining future licences (UNFDAC, 1975). Threat of punishment aside, the importance of opium as a cash crop made delicencing a significantly harsh economic sanction (Mansfield, 2001).

Furthermore, communal punishments placed a social restraint on farmers. An entire community's crops could be eradicated for the excess production of one farmer (ECOSOC, 1996, cited in Riley, 1993; Farrell, 1998), while the Muhtar could be heavily fined for failing to prevent or report diversion (Law No. 3298).

Since 1974, America (NNICC, 1981, 1988; DEA, 1995; US State Department, 1995-2013), ${ }^{4}$ Britain (Mansfield, 2001), Interpol (1988), UN (UNODCCP, 2000) and INCB $(1975,1977,1979,1980,1982)$ have reported how controls have limited diversion to almost nothing. As importantly, retired opium farmers interviewed by Evered (2011a, p. 310) recalled how the poppy straw method was profitable: 'People planted again, got money, got married, got land and got tractors'. Part of the reason was that as poppy straw farming is less labour-intensive than harvesting opium gum, farmers could cultivate other crops or more poppies, depending on the permission of the state (Evered, 2011b,c). The following section will look at how, and why, the intervention was implemented.

\section{Implementation}

\footnotetext{
${ }^{3}$ This increased in 1991 to between 10 and 20 years imprisonment (Jensema and Archer, 2005).

${ }^{4}$ By 1975, even the hawkish Drug Enforcement Agency acknowledged that controls were 'remarkable effective' (Warren-Gash, 1975 p. n.p.; Howe, 1980).
} 
Windle, J. (2016). 'Preventing the Diversion of Turkish Opium'. Security Journal, 29(2), pp. 213-227. Pre-publication copy

One of the most prominent barriers to implementing crime prevention is finding competent agents and persuading them to commit to a policy (Laycock and Tilley, 1995; Laycock, 2006). At the top level of decision making, external actors, principally America (Uslu, 2003) and the UN (Greenfield and Nanby, 1974; INCB, 1974), had been pressuring successive Turkish governments to prevent diversion since the late 1950s (Windle, forthcoming). Turkey eventually succumbed to external pressures because it felt that opium diversion was weakening its international reputation while damaging Turkish-American relations (America had threatened to remove economic aid) (Uslu, 2003). Increased revenue from taxation may have been an additional motivation.

Coercion aside, the UN provided significant incentives, including part financing the poppy straw processing plant (Bayer, 1983; Kamminga, 2007), and once controls were administered providing US\$5 million for counter-narcotic support (Land, 1981). Between 1974 and 1992, the UN Fund for Drug Abuse Control funded: several vehicles (including 94 jeeps in 1974/1975), communication equipment, two aircrafts for aerial survey (one to the TMO and one to the gendarmerie) (Kayaalp, 2001) and the construction of storage facilities (Government of Turkey, 1986a). The UN also provided counter-narcotics training and rural technical advice (Government of Turkey, 1986b). The International Bank of Reconstruction and Development provided financial advice and funded crop substitution projects in two opiumproducing provinces to lessen dependence on opium (UNFDAC, 1975; Kayaalp, 2001).

Three primary institutions, below the government, were persuaded to be responsible for monitoring licence adherence: The gendarmerie, TMO and farming communities. It is possible that TMO agricultural agents could have been uncomfortable with what may be perceived as a policing role and the gendarmerie with deviation from traditional law enforcement (see Pease, 2006). The external funds provided to the gendarmerie and TMO may, however, have facilitated compliance. The Turkish Interior Minister, for example, supported American calls for prohibition in 1968 as a mean of attracting resources (Uslu, 2003). In terms of Muhtars and local farming communities, it is likely that they were persuaded by being permitted to resume farming a profitable crop (INCB, 1972). 
Windle, J. (2016). 'Preventing the Diversion of Turkish Opium'. Security Journal, 29(2), pp. 213-227. Pre-publication copy

The government and external actors, therefore, used incentives as levers (Laycock and Tilley, 1995; Pease, 2006) to persuade competent institutions to implement the intervention. These incentives were supported by coercion in the form of legislation (that is, Degree 7/8522; Degree 7/9204) passed by a 'strong, centralist, bureaucratic state' (Koker, 1995, p. 52; Bovenkerl and Yesilgöz, 2006). These factors may have also reduced the fragility of interagency cooperation (Laycock and Tilley, 1995) central to the intervention.

Unlike many crime prevention policies, the interventions effectiveness did not 'fade over time' (Laycock and Tilley, 1995, p. 565). This may have something to do with the economic, political and institutional self-interest of implementing institutions. Not only did farmers receive a steady income from a culturally important crop, but the state benefitted from taxes, external funding and points for good behaviour from the international community. The US State Departments annual narcotics control report, for example, would often commend Turkey for its success in preventing diversion. This may have buffered Turkey against some of the criticisms levelled at its negligent approach to counter-trafficking. In short, without positive reinforcement, and financial assistance from external agencies, it is possible that Turkey's commitment may have waned.

In addition, as the intervention made the Turkish supply more expensive and less available, traffickers may have turned their attention to cheaper and more reliable sources of production, such as Afghanistan. Deceasing demand may have helped maintain farming community's compliance.

While lack of information is often a major factor in policy failure (Laycock and Tilley, 1995; Bullock et al, 2002; Brown, 2006), the Turkish intervention started from an informed foundation. Not only had external agencies been collecting data on diversion for a number of years, the policy was the outcome of three decades of organisational learning about how to best prevent diversion (Windle, forthcoming). For example, without information about the mechanics of opium farming and diversion, the state would have been unable to direct its resources to the 'hot spots' and 'hot times' (that is, harvest) of diversion (Wikström, 1995). The information in addition helped establish well-defined policy aims and objectives, a factor proven to facilitate implementation success (Bullock et al, 2002; Brown, 2006). 
Windle, J. (2016). 'Preventing the Diversion of Turkish Opium'. Security Journal, 29(2), pp. 213-227. Pre-publication copy

In short, the intervention succeeded because it was theoretically sound and 'practical and realistic', while political leaders (INCB, 1972, p. 20) and capable institutions were motivated through self-interest to successfully implement a policy built upon an informed foundation.

\section{Discussion}

It will be argued here that the primary factor in Turkish success was the administration of a combination of seven techniques provided by SCP to increase the effort and risk, while reducing rewards and removing excuses. Reuter (1985, p. 92) is, however, accurate that Turkish success was dependent on the presence of a strong central government, which 'could enforce laws without risk of revolt' (also Evered, 2011b). The techniques of SCP would have been difficult to administer if the state had not increased authority over opium growing regions from the 1940s.

The poppy straw process helped increase the effort it takes to divert opium. Poppy straw is bulky and therefore difficult to smuggle. The extraction of morphine from poppy straw involves the procurement of expensive technology, which is difficult to conceal. As such, traffickers have little interest in procuring poppy straw (Bayer, 1983; West, 1992; Mansfield, 2001). Although farmers could incise poppy capsules to extract opium gum, this was prevented by surveillance of opium poppy fields by Ajans and Muhtars during harvest. Therefore, although the poppy straw method increased the effort it took to divert opium, the effectiveness of controls centred upon a combination of preventive techniques. Contrary to some analysis, the introduction of the poppy straw method was insufficient by itself.

Risk was increased by mandating elected village representatives to monitor for diversion, and by the threat of communal civil sanctions. American, Australian and British research suggests that the norm among many rural communities is to not report crimes, often due to distrust of the police (Donnermeyer et al, 2010). This distrust was magnified in rural Turkey where there was little state presence until the 1940s. The provision of communal punishments, employment of village representatives and provision of economic incentives thus engineered guardianship. More formal surveillance was provided by gendarmes and agricultural experts. Anonymity was reduced by mandating all licenced poppy straw farmers to carry their registration identification while at work. 
Windle, J. (2016). 'Preventing the Diversion of Turkish Opium'. Security Journal, 29(2), pp. 213-227. Pre-publication copy

Table 2 SCP techniques employed to prevent diversion of regulated opium

\begin{tabular}{|c|c|c|c|}
\hline Increase the effort & Increase the risk & Reduce rewards & Remove excuses \\
\hline $\begin{array}{l}\text { Target harden: The } \\
\text { poppy straw process } \\
\text { makes it } \\
\text { harder to divert } \\
\text { opium to the black } \\
\text { market }\end{array}$ & $\begin{array}{l}\text { Reduce anonymity: } \\
\text { Licencing scheme } \\
\text { IDs } \\
\text { Strengthen formal } \\
\text { surveillance: Police, } \\
\text { aerial surveillance } \\
\text { and agricultural } \\
\text { experts }\end{array}$ & $\begin{array}{l}\text { Fair prices and risk } \\
\text { of arrest increase } \\
\text { rewards for } \\
\text { compliance and risks } \\
\text { of non-compliance }\end{array}$ & $\begin{array}{l}\text { Assist compliance: } \\
\text { Fair prices and } \\
\text { ease of sale }\end{array}$ \\
\hline
\end{tabular}

The relative rewards of diversion were reduced by providing farmers with effective procurement practices offering fair prices and easy market access. Furthermore, by administering effective law enforcement, and advertising strict civil, criminal and communal punishments, the state reduced the rewards against the potential risk.

Straightforward and simple procurement systems reduced excuses for farmers selling their produce on the black market. Farmers may have continued to risk selling opium to private (illicit) merchants if the state monopoly had failed to provide a fair price, quick payment or access to credit, especially as many merchants are willing to offer such benefits during the procurement of illicit opium (Chouvy and Laniel, 2007). Excuses were limited by informing farmers of the rules of their licence and making them aware of potential sanctions.

In terms of implementation, Turkey started from an informed foundation. This helped in the development of an intervention with focused aims and objectives, which dovetailed the self-interest of the state and implementing institutions (Table 2). 
Windle, J. (2016). 'Preventing the Diversion of Turkish Opium'. Security Journal, 29(2), pp. 213-227. Pre-publication copy

\section{Conclusion}

Before 1972, Turkey was one of the world's largest sources of illicit opium, the majority of which was diverted from the state monopoly. Since 1974, however, effective controls of poppy straw production have reduced diversion to almost nothing. Turkey thus represents an example of successful drug control and agricultural crime prevention. Although it is unfortunate that the policy was not analysed during the 1970s and 1980s, so that more specific data could have been collected, it is sufficient to show that diversion declined to almost nothing after the introduction of a combination of SCP techniques.

The success of Turkish controls centred upon the administration of a number of - what would today be considered - SCP techniques. It increased the effort and risk of diverting opium, while removing excuses and reducing the rewards by increasing the relative rewards of compliance. Furthermore, the intervention was implemented by institutions motivated by economic, institutional and political self-interest, and based on an informed foundation.

Evidence from this single case study may suggest that SCP techniques could be used to prevent the high levels of diversion reported in India, one of the world's largest sources of licit opium to the pharmaceutical industry and, due to diversion, likely one of the world's largest sources of illicit opium (Windle, 2011, 2012). Although careful analysis of the 'local political, organisational and personal realities' (Laycock and Tilley, 1995, p. 575) would of course be required. That there is, at present, little incentive for the Indian government and rural communities to support such a policy change may, however, represent a significant barrier. While recent reports on the estimated level of diversion (Mansfield, 2001; Paoli et al, 2009; Windle, 2011, 2012) have gone some way to highlighting the issue, given that little Indian opium is exported, it is unlikely that the government will be placed under the external pressures that helped motivate Turkey. A wider application of these findings is that opportunity theories may be particularly appropriate for the prevention of agricultural theft (Donnermeyer and Barclay, 2005; Mears et al, 2007; Donnermeyer et al, 2010).

\section{References}


Windle, J. (2016). 'Preventing the Diversion of Turkish Opium'. Security Journal, 29(2), pp. 213-227. Pre-publication copy

Akçasu, A. (1952) The changes experienced by the narcotics monopoly in Turkey. Bulletin of Narcotics 3(1): 6-9.

Alexander, C. (2002) Personal States: Making Connections between People and Bureaucracy in Turkey. Oxford: Oxford University Press.

Bayer, I. (1983) The monitoring of trade in and control of psychotropic substances to guard against their diversion. Bulletin on Narcotics 35(4): 3-13.

Block, A.A. (1989) European drug traffic and traffickers between the wars: The policy of suppression and its consequences. Journal of Social History 23(2): $315-337$.

Bovenkerk, F. and Yesilgöz, Y. (2006) The Turkish Mafia. Reading, UK: Milo.

British Foreign and Commonwealth Office. (1974) Records of a Meeting in United Nations Department: Report of United Nations Ministry to Turkey 26th August - 10 September. Kew, London: British National Archives, FC0 9/2130.

British Foreign Office. (1961) British Embassy, Tehran to Foreign Office. 22 June. Kew, London: British National Archives, FO 371/157503.

British Foreign Office. (1966) CENTO. Report of the third session of the working party on narcotics control. 1st June. Kew, London: British National Archives, $371 / 186536$.

Brown, R. (2006) The role of project management in implementing community safety initiatives. In: J. Knutsson and R.V. Clarke (eds.) Putting Theory to Work: Implementing Situational Crime Prevention and Problem-Oriented Policing. Devon, UK: Willan.

Brundage, W. and Mitchell, W. (1977) Towards an understanding of opium poppy production in Turkey. Journal of Asian and African Studies 12(1): 259-168.

Bulletin of Narcotics. (1949) Opium production throughout the world. Bulletin of Narcotics 1(1): 6-38.

Bulletin of Narcotics. (1950) The cultivation of the opium poppy in Turkey. Bulletin of Narcotics 2(1): 13-25.

Bulletin of Narcotics. (1953) Illicit traffic in opium. Bulletin of Narcotics 5(3): 24-29.

Bullock, K., Farrell, G. and Tilley, N. (2002) Funding and Implementing Crime Reduction Projects. Home Office Report 13. London: Home Office. 
Windle, J. (2016). 'Preventing the Diversion of Turkish Opium'. Security Journal, 29(2), pp. 213-227. Pre-publication copy

Chouvy, P. and Laniel, L.R. (2007) Agricultural drug economies: Cause or alternative to intra-state conflicts? Crime, Law and Social Change 48(2): 133-150.

CINC (Committee on International Narcotics Control). (1972) World Opium Survey 1972. Washington DC: US Government Printing Office.

Clarke, R.V. (2008) Situational crime prevention. In: R. Wortley and L. Mazerolle (eds.) Environmental Criminology and Crime Analysis. Devon, UK: Willan.

CND (Commission on Narcotic Drugs). (1944-1957) Summary of Annual Reports of Governments. New York: CND.

Cornish, D.B. and Clarke, R.V. (2008) The rational choice perspective. In: R. Wortley and L. Mazerolle (eds.) Environmental Criminology and Crime Analysis. London: Willan Publishing.

DEA (Drug Enforcement Agency). (1995) Drug Trafficking in Southwest Asia and the Central Asian States: Drug Intelligence Report. DEA-95055.

Decree No.7/8522. (1974) Decree to Authorize Opium Poppy Cultivation in the Seven Provinces during 1974-1975, http://www.unodc.org/doc/enl/197446.pdf, accessed 18 January 2009.

Decree No.7/9204. (1975) in Official Gazette, No.15120, 16 January, http://www.unodc.org/doc/enl/1975-9.pdf, accessed 18 January 2009.

Donnermeyer, J.F. and Barclay, E. (2005) The policing of farm crime. Police Practice and Research: An International Journal 6(1): 3-17.

Donnermeyer, J.F., Barclay, E. and Mears, D.P. (2010) Policing agricultural crime. In: R.I. Mawby and R. Yarwood (eds.) Rural Policing and Policing the Rural. London: Ashgate.

Economist. (1974) Poppy Power, 13 July.

Eisenlohr, L.E.S. (1934) International Narcotics Control. London: George Allen \& Unwin.

Epstein, E. (1977) Agency of Fear: Opiates and Political Power in America. New York: Putnam's and Son.

Erinç, S. and Tuncdilek, N. (1952) The agricultural regions of Turkey. Geographical Review 42(2): 179-203.

Evered, K.T. (2011a) 'Poppies are democracy!' A critical geopolitics of opium eradication and reintroduction in Turkey. Geographical Review 101(3): 299331. 
Windle, J. (2016). 'Preventing the Diversion of Turkish Opium'. Security Journal, 29(2), pp. 213-227. Pre-publication copy

Evered, K.T. (2011b) Traditional ecologies of the opium poppy and oral history in rural Turkey. Geographical Review 101(2): 164-182.

Evered, K.T. (2011c) The opium poppy in Turkey: Alternative perspectives on a controversial crop. Focus on Geography 54(1): 1-10.

Farrell, G. (1998) A global empirical review of drug crop eradication and United Nations crop substitution and alternative development strategies. Journal of Drug Issues 28(2): 395-436.

Fyjis-Walker. (1974) US/Turkish Relations. Letter to A.C. Goodison (FCO). Kew, London: British National Archives, FCO 9/2129.

GOA (Government Accounting Office) (1972) Efforts to Prevent Heroin from Illicitly Reaching the United States. Washington DC: Government Accounting Office.

GOA Government Accounting Office (1975) If the United States is to Develop an Effective International Narcotics Control Program, Much More Must Be Done. Washington DC: Government Accounting Office.

Government of Turkey. (1986a) Facts on Turkish Poppy. Ankara, Turkey: Directorate General of Press and Information.

Government of Turkey. (1986b) The Turkish Program has Been a Complete Success. Ankara, Turkey: Directorate General of Press and Information.

Government of Turkey. (1988) Turkey’s Narcotics Control in Turkey. Ankara, Turkey: Ministry of Health and Social Assistance General Directorate of Pharmaceuticals.

Greenfield, H. (1974) Poppy Cultivation in Turkey. Kew, London: British National Archives, FCO 9/2129.

Greenfield, H. and Nanby, M.C. (1974) Report and Recommendations of the United Nations Mission to Turkey, 26 August - 10 September 1974. British National Archives, Kew, London: FCO 9/2129.

Grey, W.A. (1925) The opium problem. Annals of the American Academy of Political and Social Science 122(1): 148-159.

Holahan, J. and Henningsen, P. (1972) The economics of heroin. In: The Ford Foundation (ed.) Dealing with Heroin: A Report to the Ford Foundation. London: Praeger.

Howe, M. (1980) Turkish farmers turn bitterly from opium poppy, New York Times, 28 November. 
Windle, J. (2016). 'Preventing the Diversion of Turkish Opium'. Security Journal, 29(2), pp. 213-227. Pre-publication copy

INCB. International Narcotics Control Board (1968-1998) Report of the INCB UN: New York. E/INCB/

Interpol. (1988) The Quest Review. Vienna, Austria: Interpol.

Jensema, E. and Archer, G. (2005) Licensed opium cultivation and production in the main producing countries. In: Senlis Council (ed.) Feasibility Study on Opium Licensing in Afghanistan for the Production of Morphine and Other Essential Medicines. London: Senlis Council.

Kamminga, J. (2007) The political history of Turkey's opium licensing system for the production of medicines: Lessons for Afghanistan. Senlis Council, www.icosgroup.net/.../Political_History_Poppy_Licensing_Turkey_

May_2006.pdf, accessed 12 October 2008.

Kayaalp, S.O. (2001) Success Stories in International Drug Control: Turkey. Unpublished document.

Klose, K. (1981) Accused Turk looked for exit from poverty. The Washington Post, 22 May.

Koker, L. (1995) Local politics and democracy in Turkey: An appraisal. Annals of the American Academy of Political and Social Science 540(1): 51-62.

Kolars, J.F. (1967) Types of rural development. In: F.C. Shorter (ed.) Four Studies on the Economic Development of Turkey. London: Frank Cass and Co.

Lamour, K. and Lamberti, M.R. (1974) The Second Opium War. Translated by P. Ross and B. Ross. London: Allen Lane.

Land, T. (1981) Turkey challenges its illegal opium industry. Christian Science Monitor, 7 December.

Laycock, G. (2006) Implementing crime reduction measures: Conflicts and tensions. In: J. Knutsson and R.V. Clarke (eds.) Putting Theory to Work: Implementing Situational Crime Prevention and Problem-Oriented Policing. Devon, UK: Willan.

Laycock, G. and Tilley, N. (1995) Implementing crime prevention. In: M. Tonry and D. Farrington (eds.) Building a Safer Society, Crime and Justice: A Review of Research. Chicago, IL: University of Chicago Press.

League of Nations. (1931) Commission of Inquiry into the Control of OpiumSmoking in the Far East. C.635.M.254.1930. 
Windle, J. (2016). 'Preventing the Diversion of Turkish Opium'. Security Journal, 29(2), pp. 213-227. Pre-publication copy

League of Nations. (1936) Nineteenth Assembly: Seventh Committee. Traffic in Opium and Other Dangerous Drugs. A.VII/5.1936.

League of Nations. (1938) Advisory Committee on Traffic in Opium: Report to the Council Concerning the Preparatory Work for a Conference to Consider the Possibility of Limiting and Controlling the Cultivation of the Opium Poppy and the Production of Raw Opium and Controlling Other Raw Material for the Manufacture of Opium Alkaloids. XI.1.

Mansfield, D. (2001) An analysis of licit poppy cultivation: India and Turkey, http://www.davidmansfield.org/policy_advice.php, accessed 12 October 2008.

MacLeod, I. (1980) Review of Turkish Customs Department. UK Customs and Excise.

McCoy, A. (2003) The Politics of Heroin: CIA Complicity in the Global Drug Trade. Chicago, IL: Lawrence Hill.

Mears, D.P., Scott, M.L., Bhati, A.S., Roman, J., Chalfin, A. and Jannetta, J. (2007) Process and Impact Evaluation of the Agricultural Crime, Technology, Information, and Operations Network (ACTION) Program. Florida: Urban Institute.

Meyer, K. and Parssinen, T. (2002) Webs of Smoke: Smugglers, Warlords, Spies, and the History of the International Drug Trade. Oxford: Rowman and Littlefield.

Murphy, M. and Steele, R. (1971) The World Heroin Problem. Washington DC: US Government Printing Office.

Musto, D. (1987) The American Disease: Origins of Narcotics Control. Oxford: Oxford University Press.

Newsday. (1974) The Heroin Trail. London: Souvenir Press.

NNICC (National Narcotics Intelligence Consumers Committee). (1981) The Supply of Drugs to the US Illicit Market. Washington DC: US Government Printing Office.

NNICC (National Narcotics Intelligence Consumers Committee). (1988) The Supply of Drugs to the US Illicit Market. Washington DC: US Government Printing Office.

Pamuk, S. (1991) War, state economic policies and resistance by agricultural producers in Turkey, 1939-1945. In: J. Waterbury and F. Kazemi (eds.) 
Windle, J. (2016). 'Preventing the Diversion of Turkish Opium'. Security Journal, 29(2), pp. 213-227. Pre-publication copy

Peasant Politics in the Modern Middle East. Florida: University Presses of Florida.

Paoli, L., Greenfield, V.A. and Reuter, P. (2009) The World Heroin Market: Can Supply be Cut? Oxford: Oxford University Press.

PCOB (Permanent Central Opium Board). (various years) Report to the Economic and Social Council on the Work of the Board. Geneva, Switzerland: United Nations, E/OB

Pease, K. (2006) Mindsets, set minds and implementation. In: J. Knutsson and R.V. Clarke (eds.) Putting Theory to Work: Implementing Situational Crime Prevention and Problem-Oriented Policing. Devon, UK: Willan.

Reuter, P. (1985) Eternal hope: America's quest for narcotics control. The Public Interest 79(2): 79-95.

Riley, J.K. (1993) Snow Job? The Efficacy of Source Country Cocaine Policies. California: RAND.

Robins, P. (2007) The opium crisis and the Iraq war: Historical parallels in TurkeyUS relations. Mediterranean Politics 12(1): 17-38.

Robins, P. (2008) Back from the brink: Turkey's ambivalent approaches to the hard drugs issue. Middle East Journal 62(4): 630-651.

Rottenberg, S. (1968) The clandestine distribution of heroin, its discovery and suppression. The Journal of Political Economy 76(1): 78-90.

Rustow, D.A. (1967) Politics and development policy. In: F.C. Shorter (ed.) Four Studies on the Economic Development of Turkey. London: Frank Cass and Co.

Schmidt, J. (1998) From Anatolia to Indonesia: Opium Trade and the Dutch Community in Izmir, 1820-1940. Leiden, the Netherlands: Nederlands Instituute voor het Nabijie Oosten.

Spain, J.W. (1975) The United States, Turkey and the Poppy. The Middle East Journal 29(3): 295-309.

Times. (1931) The Trade in Opium, 27 May.

TMO-Alkasan. (1989) TMO-Alkasan Turkish Opiates Board. Ankara, Turkey: TMO.

Turkish Embassy, London. (1975) Measures Taken by the Turkish Government to Control the Production of Opium. British National Archives, Kew, London: FCO 61/1369. 
Windle, J. (2016). 'Preventing the Diversion of Turkish Opium'. Security Journal, 29(2), pp. 213-227. Pre-publication copy

Turkish National News Agency. (1981) Turkish Check on Opium Plantations. In BBC Summary of World Broadcasts. 27 February.

Turnbull, J.H. (1972) Opium Narcotics: A World Survey of the Illicit Traffic. The Royal Military College of Science: Technical Report AC/R/5. British National Archives, Kew, London: FCO 40/462.

UNFDAC (UN Fund for Drug Abuse Control). (1975) The Cultivation of Opium Poppy in Turkey. MNAR/8/1975 GE.75-8207.

UNODCCP (UN Office for Drug Control and Crime Prevention). (2000) World Drug Report. Oxford: Oxford University Press.

US State Department. (1995-2013) International Narcotics Control Strategy Report. Washington DC: US State Department.

Uslu, N. (2003) The Turkish-American Relationship between 1947 and 2003: The History of a Distinctive Alliance. New York: Nova.

Warren-Gash. (1975) To C.S. Wright (FCO). Turkish Opium Poppy Cultivation. 9 September. British National Archives, Kew, London: FCO 61/1369.

West, C.S. (1992) Turkey and India. In: S. McDonald and B. Zagarid (eds.) International Handbook on Drug Control. Westport, CT: Greenwood Press.

Wikström, P.O. (1995) Preventing city centre street crimes. In: M. Tonry and D. Farrington (eds.) Building a Safer Society, Crime and Justice: A Review of Research. Chicago, IL: University of Chicago Press.

Windle, J. (2011) Poppies for medicine in Afghanistan: Historical lessons from India and Turkey. Journal of Asian and African Studies 46(6): 663-677.

Windle, J. (2012) Insights for contemporary drug policy: A historical account of opium control in India and Pakistan. Asian Journal of Criminology 7(1): 5574.

Windle, J. (forthcoming) A very gradual suppression: A history of Turkish opium controls, 1933-1974. European Journal of Criminology (accepted for publication).

Zerel, U., Ahrens, B. and Gerz, P. (2005) Documentation of a heroin manufacturing process in Afghanistan. Bulletin of Narcotics 61(1/2): 11-33.

Zürcher, E. (1998) Turkey: A Modern History. London: I.B. Tauris. 